\title{
The Effects of Various Doses of Azadirachta indica A. Juss. Seed Cake against Aphis gossypii (Glover) and Growth Characters of Red Chili Plants (Capsicum annuum L.)
}

\author{
Ardi Zulfikar Muchlis* \\ Alumny of Agrotechnology Study Program, Department of Plant Pests and Diseases, Agriculture Faculty, Universitas \\ Padjadjaran, Jatinangor, West Java 45363 \\ *Address for corresponding : danardono12@gmail.com
}

Received June 10, 2021; revised June 21, 2021; accepted June 28, 2021

\begin{abstract}
Neem plant is used as plant-based insecticide because all parts of the plant have insecticides activities. The utilization of neem plants as plant-based insecticides is generally only in the seed parts, but the extraction of neem seed extract has not been used because it is considered as waste. The utilization of neem seed cake as a natural insectiside is one way to recycle neem seed cake which is known to contain active ingredients of neem seed oil. Apart from its use as an insecticide, neem seed cake can also be used as an organic fertilizer. This study aimed to determine the effect of application of various doses of neem seed cake to A. gossypii on chili plants. The experiment used a randomized block design with 7 treatments and 4 replications. The treatments included control, neem seed cake doses of $25 \mathrm{gr}, 50 \mathrm{gr}, 75 \mathrm{gr}, 100 \mathrm{gr}, 125 \mathrm{gr}$, and a comparative treatment of carbofuran active ingredients. A. gossypii imago were introduced in 20 red chili plants per plant. The results showed the application of a dose of 50 gr of neem seed cake per polybag effectively suppressed A. gossypii populations and gave the best effect on some chili plant growth characters such as leaf chlorophyll content, plant height, leaf hardness of chili plant and levels of $\mathrm{N}$ element absorbed.
\end{abstract}

Keywords: Neem seed cake, Aphis gossypii, Chlorophyll content, $\mathrm{N}$ absorbed, Leaf Hardness

\section{ABSTRAK \\ Pengaruh Berbagai Dosis Bungkil Biji Azadirachta indica A. Juss. Terhadap Aphis gossypii (Glover) dan Karakter Pertumbuhan Tanaman Cabai Merah (Capsicum annuum L.).}

Tanaman mimba dijadikan sebagai bahan insektisida nabati karena semua bagian tanamannya memiliki aktivitas biologis yang bersifat insektisida. Pemanfaatan tanaman mimba sebagai insektisida nabati pada umumnya hanya pada bagian biji, akan tetapi bungkil biji mimba sisa ekstraksi belum dimanfaatkan karena dianggap sebagai limbah. Pemanfaatan bungkil biji mimba sebagai insektisida nabati merupakan salah satu cara untuk mendaur ulang bungkil biji mimba yang diketahui masih memiliki minyak biji mimba dengan kandungan bahan aktif. Selain kegunaannya sebagai insektisida, bungkil biji mimba juga dapat digunakan sebagai bahan pupuk organik. Penelitian ini bertujuan untuk mengatahui pengaruh aplikasi berbagai dosis bungkil biji mimba terhadap A. gossypii pada tanaman cabai. Percobaan menggunakan rancangan acak kelompok dengan 7 perlakuan dan 4 ulangan. Perlakuan meliputi kontrol, dosis 25 gr, 50 gr, 75 gr, 100 gr, 125 gr, dan perlakuan pembanding insektisida bahan aktif karbofuran. Imago A. gossypii diinfestasikan pada tanaman cabai merah sebanyak 20 ekor per tanaman. Hasil penelitian menunjukkan aplikasi dosis 50 gr bungkil biji mimba per polibag efektif menekan populasi kutu daun A. gossypii dan memberikan pengaruh terbaik pada beberapa karakter pertumbuhan tanaman cabai misalnya kandungan klorofil daun, tinggi tanaman, kekerasan daun tanaman cabai dan kadar serapan unsur N.

Kata Kunci: Bungkil biji mimba, Aphis gossypii, Kandungan klorofil, Serapan-N, Kekerasan daun

\section{PENDAHULUAN}

Jenis tumbuhan yang dapat digunakan sebagai bahan dasar insektisida nabati, misalnya tanaman mimba (Azadirachta indica), daun wangi (Melaleuca bracteata), selasih (Ocimum spp.), serai (Cymbopogon nardus), cengkeh (Syzygium aromaticum), akar tuba (Deris eliptica), piretrum (Chrysanthemum cinerariaefolium), kacang babi (Tephrosia vogelii), gadung (Dioscorea hispida), tembakau (Nicotiana tabacum), Sirsak (Annona muricata), srikaya (Annona squamosa), suren (Toona sureni), dan lainnya (Puslitbangbun, 2012). Dari sekian banyak tumbuhan di atas, mimba merupakan bahan dasar insektisida nabati yang sudah banyak digunakan (Kardinan \& Dhalimi, 2003).
Mimba dijadikan sebagai bahan insektisida nabati karena semua bagian tanamannya memiliki aktivitas biologis yang bersifat insektisida (Puslitbangbun, 2012). Aktivitas biologis dari tanaman mimba disebabkan oleh kandungan senyawa bioaktif limonoid, antara lain azadirachtin, salanin, meliatriol, dan nimbin (Debashri \& Tamal, 2012). Senyawa azadirachtin terbukti efektif untuk mengendalikan lebih dari 300 spesies serangga hama termasuk hama-hama penting pada tanaman budidaya seperti kutu daun, penggorok daun, ulat grayak, dan kutu putih (Samsudin, 2011). Senyawa azadirachtin dapat menyebabkan kematian spontan ataupun kematian secara bertahap pada serangga hama (Wowiling, 2010). Penelitian Kraiss \& Cullen (2008) 
juga menunjukkan bahwa aplikasi insektisida berbasis mimba dapat mengurangi rentang hidup dari kutu daun A. glycine pada kedelai.

Senyawa bioaktif tersebut banyak terkandung pada bagian daun dan biji mimba (Saenong, 2016). Berdasarkan penelitian Rao (2012), satu ton biji mimba yang diproses, dapat menghasilkan $1,5 \mathrm{~kg}$ bahan aktif Azadirachtin, $200 \mathrm{~kg}$ minyak mimba dan $780 \mathrm{~kg}$ bungkil biji mimba.

Pemanfaatan tanaman mimba sebagai insektisida nabati pada umumnya menggunakan bagian bijinya. Akan tetapi bungkil biji mimba sisa ekstraksi belum banyak dimanfaatkan karena dianggap sebagai limbah. Pemanfaatan bungkil biji mimba sebagai insektisida nabati merupakan salah satu cara untuk mendaur ulang bungkil biji mimba yang diketahui masih memiliki kandungan bahan aktif sehingga perlu dilakukan penelitian lebih lanjut (Yusriah, 2017).

Selain kegunaannya sebagai insektisida, bungkil biji mimba juga dilaporkan dapat digunakan sebagai bahan pupuk organik. Bungkil biji mimba dapat meningkatkan kandungan organik di dalam tanah dengan cara mengurangi tingkat basa tanah dan menghasilkan asam organik selama dekomposisi. Karena sifat alaminya, mimba sangat kompatibel dengan mikroba tanah, dapat mengoptimalkan kondisi rhizosfer dan memastikan tekstur yang lebih kuat pada tanah, serta kapasitas menahan air yang lebih tinggi dan aerasi di dalam tanah untuk pengembangan akar yang lebih baik (Rao, 1987).

Bungkil biji mimba juga dapat membuat tanah lebih subur karena bahan alaminya yang dapat memperlambat bakteri tanah dalam mengkonversi ammonium menjadi nitrat $\left(\mathrm{NO}_{3}{ }^{-}\right)$. Sebagai penghambat nitrifikasi, mimba memperpanjang ketersediaan nitrogen untuk tanaman hari panjang maupun hari pendek (Saxena et al., 1984). Pengaplikasian mimba bersama dengan pupuk nitrogen juga dapat memperlambat proses konversi senyawa nitrogen dalam amonia, nitrat dan nitrit, serta meningkatkan efisiensi tanah (Sahrawat \& Parmar, 1975). Bungkil biji mimba diaplikasikan dengan cara mencampurkannya dengan tanah di atas dan di sekitar daerah perakaran.

Keefektifan bungkil biji mimba sebagai insektisida nabati dipengaruhi oleh dosis yang digunakan. Bungkil biji mimba telah banyak digunakan di daerah Gurugram India dengan dosis anjuran untuk tanaman cabai yang tergolong tanaman semusim yaitu sebesar 200-350 kg/acre (Agroorganix, 2018). Sedangkan dosis yang dianjurkan untuk tanaman sayuran secara umum di daerah Bengaluru India yaitu sebesar $200 \mathrm{~g}$ per $\mathrm{m}^{2}$ (Agro Extracts Ltd., 2018). Menurut data Neempedia (2018), untuk tanaman hortikultura memerlukan dosis $1000 \mathrm{~kg} \mathrm{ha}^{-1}$ bungkil biji mimba. Berdasarkan penelusuran data, diperoleh dosis bungkil biji mimba yang menjadi anjuran untuk diaplikasikan pada tanaman cabai kurang lebih 100 gram per $3 \mathrm{~kg}$ tanah.
Pengaplikasian bungkil biji mimba diduga dapat mempengaruhi karakter pertumbuhan tanaman cabai. Pengaplikasian minyak biji mimba dengan dosis $30 \mathrm{~kg} / \mathrm{ha}$ dapat menghambat nitrifikasi sebesar 58\% selama jangka waktu 30 hari (Opoku et al., 2014). Berdasarkan penelitian Basharat et al. (2003), diketahui bahwa kombinasi aplikasi antara bungkil biji mimba dan pupuk kandang dengan jumlah dosis yang berbeda dari $0-15 \mathrm{~kg}$ per ha masing-masing dapat meningkatkan tinggi tanaman, peningkatan jumlah cabang dan peningkatan jumlah daun pada tanaman tomat.

Menurut Miles (1987), kutu daun cabai dapat menyebabkan kerugian lebih dari $90 \%$ jika menjadi vektor penyakit dibandingkan sebagai hama yang hanya berkisar 6-25\%. Pada populasi yang tidak terkendali, A. gossypii menyebabkan gejala klorosis, nekrosis, pengkerdilan, tanaman layu, gugurnya bunga dan buah, serta distorsi dan defoliasi pada daun (Da Costa et al., 2011).

Penelitian ini bertujuan untuk mengetahui pengaruh dari berbagai dosis aplikasi bungkil biji mimba (Azadirachta indica) terhadap kutu daun $A$. Gossypii dan pengaruhnya terhadap pertumbuhan tanaman.

\section{BAHAN DAN METODE}

\section{Metode Percobaan}

Percobaan ini dilaksanakan mulai dari bulan Januari 2019 hingga bulan Juli 2019. Percobaan dilaksanakan di Rumah Kaca Ciparanje, Departemen Hama dan Penyakit Tumbuhan, Fakultas Pertanian Universitas Padjadjaran, Jatinangor, Jawa Barat.

Metode yang digunakan adalah metode eksperimen dengan menggunakan Rancangan Acak Kelompok (RAK) (Gomez \& Gomez, 2007). Rancangan terdiri dari 7 taraf perlakuan dan 4 ulangan. Sebagai pembanding digunakan insektisida sintetik berbahan aktif karbofuran. Perlakuan dosis bungkil biji mimba yaitu $25 \mathrm{~g}$ per $3 \mathrm{~kg}$ tanah, $50 \mathrm{~g}$, $75 \mathrm{~g}, 100 \mathrm{~g}$, dan bungkil biji mimba dosis $125 \mathrm{~g}$ per 3 $\mathrm{kg}$ tanah, insektisida berbahan aktif Karbofuran dosis $2 \mathrm{~g}$ per $3 \mathrm{~kg}$ tanah, serta Kontrol.

Analisis data hasil pengamatan dilakukan dengan menggunakan software SPSS 25.0. Data dianalisis dengan sidik ragam/ANOVA (Analisis of variance) untuk mengetahui apakah ada pengaruh yang nyata dari perlakuan yang diuji. Apabila terdapat pengaruh yang nyata, maka data diuji lanjut dengan menggunakan uji Duncan pada taraf nyata 5\% untuk mengetahui perlakuan mana yang terbaik.

\section{Penanaman Cabai}

Penanaman cabai dilakukan di rumah kaca Ciparanje Universitas Padjadjaran. Suhu harian ratarata rumah kaca berkisar antara $18-38{ }^{\circ} \mathrm{C}$ dengan suhu rata-rata $21{ }^{\circ} \mathrm{C}$ pada pagi hari, $33{ }^{\circ} \mathrm{C}$ pada siang hari dan $27{ }^{\circ} \mathrm{C}$ pada sore hari. Dan kelembapan harian rata-rata di rumah kaca berkisar antara $27 \%$ - 
$83 \%$,dengan kelembapan rata-rata pada pagi hari $77 \%$, siang hari $38 \%$, dan sore hari $51 \%$.

Cabai yang digunakan ada cabai merah varietas Unpad CB2. Penanaman cabai dilakukan secara bertahap mulai dari penyeleksian benih hingga penyemaian. Sebelum penanaman, benih direndam terlebih dahulu dengan air selama \pm 12 jam kemudian ditiriskan. Setelah itu, dilakukan seleksi benih untuk kemudian disemai. Benih disemai pada lubang seedtray yang telah terisi media tanam (tanah dan pupuk kompos) dengan perbandingan 2:1. Setiap lubang pada seedtray diisi sebanyak 2 benih cabai merah. Penyemaian dilakukan selama 28 hari dengan penyiraman secara intensif serta terjadwal.

Bibit cabai hasil penyemaian yang sehat, berumur \pm 4 MST dan telah memiliki 3-4 helai daun dipindah tanamkan pada polibag berukuran $30 \times 15$ $\mathrm{cm}$. Masing-masing polibag diisi dengan $3 \mathrm{~kg}$ tanah dan berisi satu bibit cabai merah. Setelah cabai merah memasuki umur \pm 6 MST maka tanaman cabai siap untuk perlakuan.

\section{Perbanyakan Serangga Uji}

Serangga uji kutu daun A. gossypii diperoleh dari lapangan yang kemudian dilakukan identifikasi terlebih dahulu untuk memastikan bahwa serangga yang akan diuji merupakan kutu daun A. gossypii. Sampel kutu daun yang didapat diidentifikasi spesiesnya dengan menggunakan buku identifikasi "Aphids of the World Crop: An Identification and Information Guide" (Blackman \& Eastop, 2000). Identifikasi dilakukan dengan cara pembuatan preparat slide dari sampel serangga uji. Karakter kutu daun A. gossypii secara umum yaitu memiliki ciri identifikasi dari bentuk antena tuberkel, kauda dan siphunculinya. Serangga uji kutu daun A. gossypii yang digunakan yaitu imago tanpa sayap.

Kutu daun $A$. gossypii diperbanyak pada tanaman cabai yang sudah memiliki minimal 6 daun. Pemindahan kutu daun dari tanaman sumber kutudaun ke tanaman untuk perbanyakan (rearing) yaitu dengan memotong bagian tanaman yang terdapat kutu daun lalu diletakkan di tanaman rearing yang sudah berada dalam kurungan. Kutudaun akan berpindah dari tanaman sumber ke daun yang lebih segar dari tanaman rearing (Arizona, 2001). Selanjutnya diperbanyak dengan prosedur standar lalu dapat digunakan untuk percobaan dengan cara diinfestasikan pada tanaman cabai yang sudah berumur \pm 14 HST. Cabai ditanam pada polibag yang ditutup dengan kain tile dan diletakkan di rumah kaca.

\section{Persiapan Penggunaan Bungkil Biji Mimba}

Biji mimba ( $A$. indica) diperoleh dari daerah Situbondo, Jawa Timur yang dipanen pada bulan Januari tahun 2019. Bungkil biji mimba, yang diperoleh dari hasil pengepresan disertai pemanasan, ditimbang terlebih dahulu masing sebesar $25 \mathrm{gr}, 50 \mathrm{gr}$, $75 \mathrm{gr}, 100 \mathrm{gr}$, dan $125 \mathrm{gr}$ sebagai perlakuan.

\section{Aplikasi Bungkil Biji Mimba terhadap Aphis gossypii}

Bungkil biji mimba yang sudah siap diaplikasikan sesuai perlakuan dimasukkan ke dalam lubang tanah dengan kedalaman $\pm 10 \mathrm{~cm}$ dengan cara ring placement. Aplikasi dilakukan sebanyak satu kali saat tanaman berumur $\pm 6 \mathrm{MST}$. Untuk perlakuan pembanding aplikasi insektisida bahan aktif karbofuran 3GR diaplikasikan pada waktu aplikasi yang sama dengan bungkil biji mimba dengan kedalaman $\pm 10 \mathrm{~cm}$.

\section{Infestasi Aphis gossypii ke Tanaman Uji}

Tanaman cabai yang telah berumur 6 MST diinfestasi masing-masing 20 imago kutu daun $A$. gossypii per tanaman.

\section{Peubah yang diamati}

\section{Populasi Aphis gossypii}

Pengamatan populasi Aphis gossypii dilakukan setiap hari hingga hari ke-14 setelah perlakuan. Pengamatan dilakukan dengan selang waktu 24 jam. Pengamatan dilakukan dengan cara menghitung jumlah kutu daun pada setiap tanaman.

\section{Karakter Pertumbuhan Tanaman}

Pengamatan yang dilakukan adalah pengukuran tinggi tanaman, N-serapan, kandungan klorofil pada daun. Pengukuran tinggi tanaman dilakukan pada awal sebelum perlakuan, hari ke-7 dan hari ke-14. Analisis kadar N-serapan dilakukan di Laboratorium Tanaman Makro dan Mikro, Balai Penelitian Tanaman Sayuran, Lembang, Jawa Barat. Kandungan klorofil pada daun diukur menggunakan alat SPAD di akhir pengamatan pada hari ke-14 setelah perlakuan.

\section{Kekerasan Jaringan}

Penetrometer umumnya digunakan untuk menentukan nilai kekerasan atau kekenyalan suatu bahan dengan mekanisme pengukuran kedalaman tusukan jarum (Sudarmaji, 1989). Pada penelitian ini, pengukuran kekerasan jaringan diukur menggunakan analisis penetrometer di Laboratorium Fisiologi Hasil, Balai Penelitian Tanaman Sayuran.

\section{Intensitas Kerusakan Daun}

Pengamatan intensitas kerusakan daun dilakukan saat hari ke-7 aplikasi dan hari ke-14 setelah aplikasi. Kerusakan dilihat berdasarkan gejala serangan yang muncul seperti daun yang mengeriting, nekrosis dan rontok. Intensitas kerusakan daun dihitung menggunakan rumus (Walker, 1991):

$\mathrm{P}=\frac{\sum n \times v}{Z \times N} \times 100 \%$

Keterangan :

P: Intensitas kerusakan daun (\%) 
$\mathrm{n}$ : jumlah daun yang diamati dengan kategori sama $\mathrm{v}$ : nilai skor dari tiap kategori serangan

$\mathrm{N}$ : jumlah daun keseluruhan

$\mathrm{Z}$ : nilai skor tertinggi

Nilai kategori untuk masing-masing serangan sebagai berikut:

$0=$ sampel tidak terserang sama sekali

$1=$ serangan $0 \%<\mathrm{x}_{1} \leq 20 \%$ luas daun

$2=$ serangan $20 \%<\mathrm{x}_{2} \leq 40 \%$ luas daun

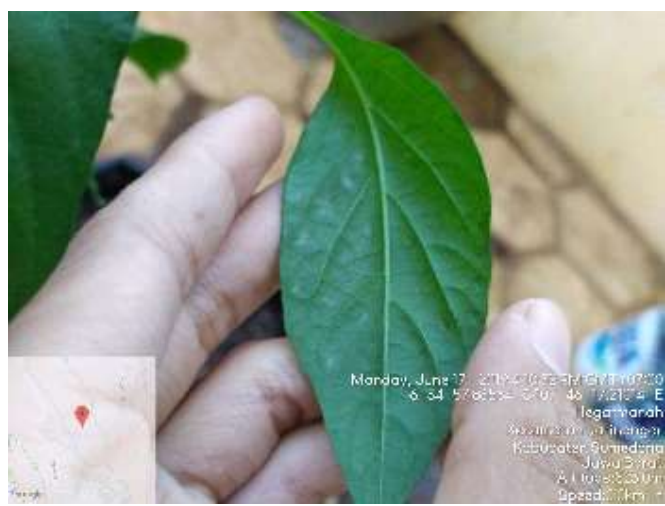

$0 \%$

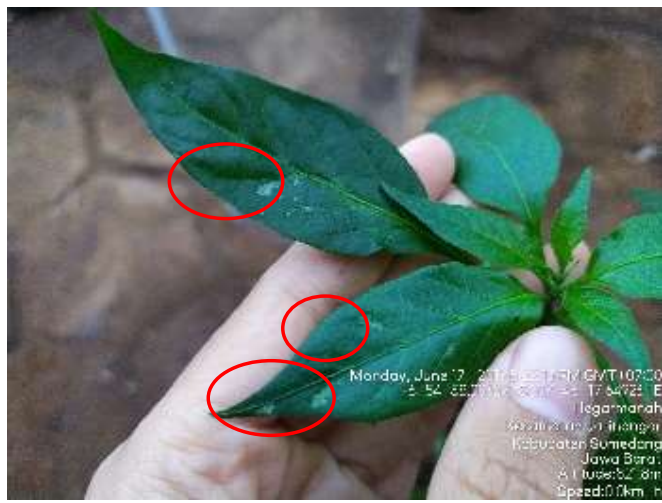

$20 \%<x_{2} \leq 40 \%$

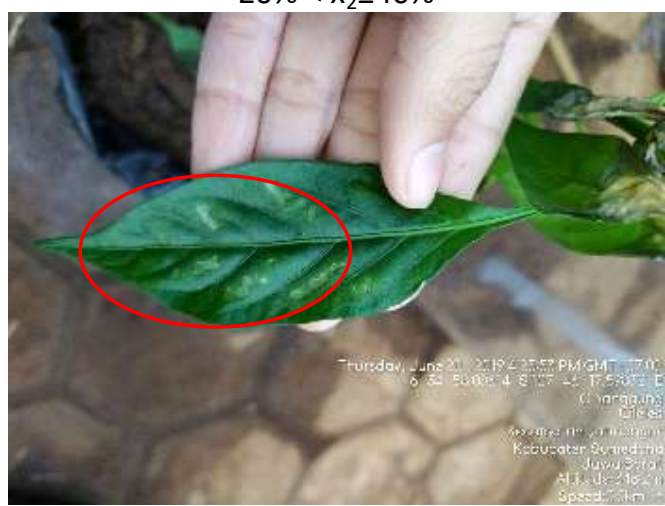

$60 \%<x_{4} \leq 80 \%$
$3=$ serangan $40 \%<\mathrm{x}_{3} \leq 60 \%$ luas daun $4=$ serangan $60 \%<\mathrm{x}_{4} \leq 80 \%$ luas daun $5=$ serangan $\mathrm{x}_{5}>80 \%$ luas daun

Perhitungan intensitas kerusakan daun tanaman cabai akibat serangan kutu daun A. gossypii dilakukan menggunakan kisaran gejala seperti yang tampak pada Gambar 1.

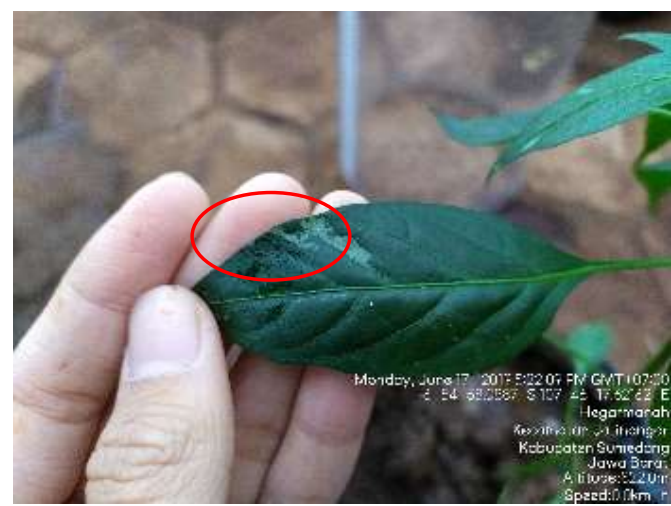

$0 \%<\mathrm{x}_{1} \leq 20 \%$

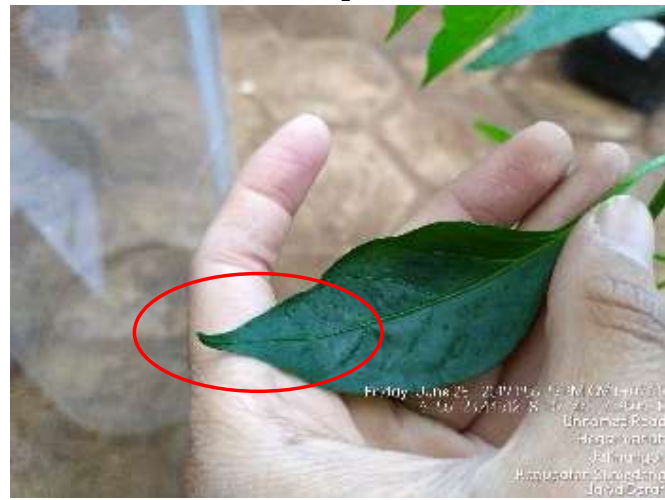

$40 \%<x_{3} \leq 60 \%$

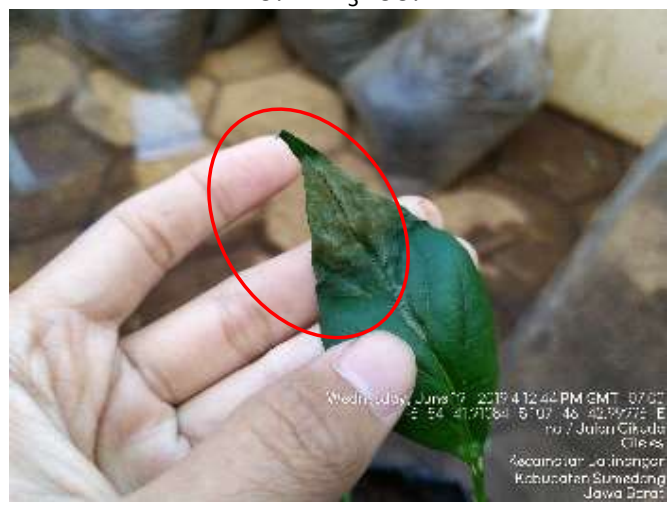

$x_{5}>80 \%$

Gambar 1. Persentase kerusakan daun saat pengamatan

\section{Gejala Fitotoksisitas}

Pengamatan sifat fitotoksisitas yang muncul pada tanaman cabai dilakukan setiap hari setelah dilakukannya perlakuan. Gejala fitotoksik pada tanaman dapat diamati dengan melihat gejala yang muncul pada daun seperti gejala terbakar atau gosong (Kardinan \& Suriarti, 2012).

\section{HASIL DAN PEMBAHASAN}

Kelimpahan populasi Aphis gossypii pada tanaman cabai yang diaplikasikan bungkil biji mimba

Berdasarkan hasil analisis statistik, aplikasi bungkil biji mimba pada media tanam terbukti dapat mempengaruhi kelimpahan populasi A. gossypii pada 
tanaman cabai. Populasi A. gossypii pada perlakuan pemberian bungkil mimba meningkat pada 2 hari pertama setelah perlakuan, yang kemudian terus menurun pada hari berikutnya.

Perlakuan pemberian bungkil biji mimba 100 gr merupakan perlakuan yang paling efektif dalam menekan populasi dengan persentase penurunan populasi $100 \%$ pada hari ke-7 dibandingkan dengan kontrol yang populasinya terus naik (Tabel 1). Diikuti oleh dosis bungkil biji mimba 25 gr, 50 gr, 75 gr dan 125 gr yang dapat menekan populasi A. gossypii hingga $100 \%$ pada hari ke-9 hingga hari ke-11 setelah perlakuan. Hal tersebut menunjukkan bahwa perlakuan pemberian bungkil mimba pada media tanam dapat secara efektif mengendalikan populasi $A$. gossypii pada tanaman cabai. Sedangkan pada perlakuan pemberian insektisida sintetik dengan bahan aktif karbofuran sebagai perlakuan pembanding hanya mengalami fluktuasi kelimpahan populasi hanya pada hari pertama setelah perlakuan. Perlakuan insektisida sintetik bahan aktif karbofuran dapat menurunkan populasi A. gossypii pada hari ke-2 setelah perlakuan dan dapat menyebabkan kematian A. gossypii hingga $100 \%$ pada hari ke-6 setelah perlakuan.

Berdasarkan penelitian Sundaram (1995) dan Sundaram (1996) dilaporkan bahwa senyawa azadirachtin dapat diserap dan ditranslokasikan melalui pembuluh xylem pada batang dan terakumulasi pada bagian-bagian tanaman yang melakukan fotosintesis seperti daun dan bagian apikal tanaman. Bahan aktif azadirakhtin disinyalir dapat diserap oleh tanaman cabai sehingga berpengaruh terhadap kelimpahan populasi A. gossypii. Kutu daun A. gossypii mencerna bahan aktif azadirachtin bersamaan dengan cairan dari daun saat melakukan aktivitas makan pada jaringan floem (Weathersbee III \& McKenzie, 2005). Selain itu, terkendalinya populasi hama tersebut dapat disebabkan karena adanya kandungan azadirachtin yang berperan dalam mengganggu fertilitas imago kutu daun pada kubis (Brevicoryne brassicae) (Pavela et al., 2004). Sinha et al. (2018) juga melaporkan bahwa aplikasi bungkil biji mimba 2 kuintal/ha dan 5 kuintal/ha dapat menurunkan populasi kutu daun Lipaphis erysimi sebesar 22,36\% dan 37,31\%. Aplikasi bungkil biji mimba $1000 \mathrm{~kg} / \mathrm{ha}$ pada penelitan Giraddi \& Varghese (2007) efektif dalam mengendalikan hama Scirtothrips dorsalis dan Polyphagotarsonemus latus.

Kandungan senyawa metabolit sekunder yang terdapat dalam bungkil biji mimba dapat terabsorpsi ke dalam tanaman dan tersebar ke jaringan tanaman melalui jaringan xylem, sehingga akan memberikan pengaruh terhadap hama dengan tipe mulut menghisap (Nathan et al., 2007). Roychoudhury (2016) melaporkan adanya kerja sistemik pada bungkil biji mimba seperti adanya efek antifeedant dan penghambat pertumbuhan pada serangga. Hal ini sejalan dengan hasil percobaan yang dilakukan. Kelimpahan populasi kutu daun A. gossypii dipengaruhi oleh dosis dari bungkil biji mimba. Pada perlakuan dosis bungkil biji mimba yang lebih tinggi memiliki kecenderungan populasi yang lebih rendah (Tabel 1).

\section{Kadar N-serapan pada tanaman cabai merah yang diaplikasikan dengan bungkil biji mimba}

Aplikasi bungkil biji mimba dapat meningkatkan kadar N-serapan pada tanaman cabai. Perlakuan pemberian dosis bungkil biji mimba sebanyak 50 gr per polibag menunjukkan peningkatan kadar N-serapan yang paling tinggi. Kadar N-serapan pada perlakuan kontrol hanya mencapai 46,3 mg/tanaman dan merupakan nilai terendah (Tabel 2). Rendahnya kadar N-serapan pada kontrol disebabkan karena tidak adanya penambahan aplikasi bungkil biji mimba yang menyebabkan jumlah $\mathrm{N}$ total tanahnya juga rendah, sehingga $\mathrm{N}$-serapan yang didapatkan tanaman menjadi rendah juga.

Aplikasi dosis bungkil biji mimba sebagai pupuk pada tanaman juga berpengaruh terhadap kutudaun A. gossypii di alam. Aplikasi bungkil biji mimba yang mengandung unsur $\mathrm{N}$ pada tanah dapat meningkatkan $\mathrm{N}$-serapan pada tanaman. Penambahan unsur $\mathrm{N}$ pada tanaman berkorelasi positif dengan warna dan ukuran A. gossypii (Rosenheim et al., 1994 \& Ebert, 1998).

A. gossypii yang terdapat pada tanaman dengan kandungan unsur $\mathrm{N}$ yang tinggi memiliki ukuran tubuh lebih besar dan warna lebih gelap. A. gossypii yang berwarna gelap dapat berkembang lebih cepat, meletakkan keturunan lebih banyak dan tubuhnya lebih besar dari pada yang berwarna cerah (Riyanto, dkk., 2016). Tanaman inang dapat mempengaruhi tingkat reproduksi, waktu perkembangan, dan fekunditas dari A. gossypii (Nevo \& Coll, 2001).

Haryadi et al. (2015) menyatakan bahwa nitrogen dibutuhkan oleh tanaman untuk pertumbuhan dan perkembangan terutama pada fase vegetatif. Nitrogen berfungsi untuk pembentukan sel, jaringan dan organ tanaman, khususnya batang dan daun. Pada saat fase pertumbuhan terutama dalam fase vegetatifnya, nitrogen dibutuhkan oleh tanaman dalam jumlah yang relatif tinggi (Novizan, 2005).

Unsur $\mathrm{N}$ pada tanaman juga memegang peranan penting sebagai penyusun klorofil, sehingga akan mempengaruhi kenampakan warna hijau pada daun dimana semakin tinggi kandungan unsur $\mathrm{N}$ maka jumlah klorofil pada daun juga akan semakin tinggi yang menyebabkan warna daun juga menjadi lebih hijau (Mangel \& Kirby, 1987). Kutu daun A.gossypii cenderung menyukai dan menyerang daun-daun muda pada tanaman dan pada bagian bawah daun serta bagian pucuk tanaman (Leite et al., 2007). Pada penelitian ini, populasi kutu daun ditemukan lebih banyak pada daun tanaman cabai yang memiliki kandungan $\mathrm{N}$ lebih rendah. Sebaliknya tingkat kelimpahan kutu daun ditemukan lebih sedikit pada daun tanaman cabai yang memiliki kandungan $\mathrm{N}$ tinggi. 
Tabel 1. Pengaruh aplikasi bungkil mimba pada media tanam tanaman cabai terhadap kelimpahan populasi A. gossypii

\begin{tabular}{|c|c|c|c|c|c|c|c|c|c|c|c|c|c|c|c|c|c|c|c|c|c|}
\hline \multirow{3}{*}{ Perlakuan } & \multicolumn{21}{|c|}{ Rata-rata Kelimpahan A. gossypii (ekor per tanaman) pada (HSP) } \\
\hline & \multicolumn{3}{|l|}{1} & \multicolumn{3}{|c|}{2} & \multicolumn{3}{|c|}{3} & \multicolumn{3}{|c|}{4} & \multicolumn{3}{|c|}{5} & \multicolumn{3}{|l|}{6} & \multicolumn{3}{|c|}{7} \\
\hline & \multicolumn{2}{|l|}{$(\mathrm{X} \pm \mathrm{SE})^{*}$} & \multirow[t]{2}{*}{$\mathrm{PP}$} & \multicolumn{2}{|l|}{$(\mathrm{X} \pm \mathrm{SE})$} & \multirow[t]{2}{*}{$\mathrm{PP}$} & \multicolumn{2}{|l|}{$(\mathrm{X} \pm \mathrm{SE})$} & \multirow[t]{2}{*}{$\mathrm{PP}$} & \multicolumn{2}{|l|}{$(\mathrm{X} \pm \mathrm{SE})$} & \multirow[t]{2}{*}{$\mathrm{PP}$} & \multicolumn{2}{|l|}{$(\mathrm{X} \pm \mathrm{SE})$} & \multirow[t]{2}{*}{ PP } & \multicolumn{2}{|l|}{$(\mathrm{X} \pm \mathrm{SE})$} & \multirow[t]{2}{*}{$\mathrm{PP}$} & \multicolumn{2}{|l|}{$(\mathrm{X} \pm \mathrm{SE})$} & $\mathrm{PP}$ \\
\hline Kontrol & $42,00 \pm 10,54$ & a & & $52,25 \pm 12,49$ & $\mathrm{~d}$ & & $68,75 \pm 14,25$ & e & & $96,50 \pm 32,20$ & e & & $113,75 \pm 35,92$ & $\mathrm{e}$ & & $151,00 \pm 55,01$ & e & & $186,50 \pm 61,99$ & $\mathrm{e}$ & \\
\hline Bungkil biji mimba 25 gr & $33,50 \pm 4,70$ & $\mathrm{a}$ & $20 \%$ & $44,25 \pm 8,58$ & $\mathrm{~cd}$ & $15 \%$ & $45,00 \pm 7,36$ & de & $35 \%$ & $52,75 \pm 10,83$ & $\mathrm{~d}$ & $45 \%$ & $43,25 \pm 9,81$ & $\mathrm{~d}$ & $62 \%$ & $37,25 \pm 8,45$ & $\mathrm{~d}$ & $75 \%$ & $28,50 \pm 6,22$ & $\mathrm{~d}$ & $85 \%$ \\
\hline Bungkil biji mimba 50 gr & $25,50 \pm 1,85$ & $\mathrm{a}$ & $39 \%$ & $28,50 \pm 6,14$ & $\mathrm{bc}$ & $45 \%$ & $20,75 \pm 4,92$ & $\mathrm{bc}$ & $70 \%$ & $18,75 \pm 4,57$ & $\mathrm{~b}$ & $81 \%$ & $16,75 \pm 4,23$ & bcd & $85 \%$ & $13,25 \pm 3,15$ & $\mathrm{bc}$ & $91 \%$ & $10,00 \pm 2,65$ & cde & $95 \%$ \\
\hline Bungkil biji mimba 75 gr & $27,00 \pm 3,14$ & $\mathrm{a}$ & $36 \%$ & $36,00 \pm 5,57$ & bcd & $31 \%$ & $28,00 \pm 4,40$ & $\mathrm{~cd}$ & $59 \%$ & $24,00 \pm 3,87$ & $\mathrm{~b}$ & $75 \%$ & $20,50 \pm 4,37$ & cd & $82 \%$ & $14,75 \pm 2,81$ & $\mathrm{bc}$ & $90 \%$ & $11,25 \pm 2,29$ & de & $94 \%$ \\
\hline Bungkil biji mimba 100 gr & $24,00 \pm 2,12$ & $\mathrm{a}$ & $43 \%$ & $27,25 \pm 5,92$ & $\mathrm{~b}$ & $48 \%$ & $14,25 \pm 2,46$ & $\mathrm{bc}$ & $79 \%$ & $8,40 \pm 1,29$ & $a b$ & $91 \%$ & $4,00 \pm 1,47$ & $\mathrm{ab}$ & $96 \%$ & $2,25 \pm 1,03$ & $\mathrm{ab}$ & $99 \%$ & $0,75 \pm 0,75$ & $a b$ & $100 \%$ \\
\hline Bungkil biji mimba 125 gr & $29,25 \pm 4,25$ & $\mathrm{a}$ & $30 \%$ & $26,75 \pm 2,46$ & $\mathrm{bc}$ & $49 \%$ & $18,50 \pm 3,50$ & $\mathrm{bc}$ & $73 \%$ & $15,00 \pm 3,20$ & $a b$ & $84 \%$ & $11,25 \pm 2,66$ & $\mathrm{bc}$ & $90 \%$ & $8,25 \pm 2,17$ & $a b$ & $95 \%$ & $4,50 \pm 2,53$ & $a b c$ & $98 \%$ \\
\hline Karbofuran & $24,25 \pm 2,63$ & $\mathrm{a}$ & $42 \%$ & $12,25 \pm 2,29$ & $\mathrm{a}$ & $77 \%$ & $6,75 \pm 1,49$ & $\mathrm{a}$ & $90 \%$ & $3,25 \pm 1,97$ & $\mathrm{a}$ & $97 \%$ & $1,75 \pm 1,75$ & $\mathrm{a}$ & $98 \%$ & $0,75 \pm 0,75$ & $\mathrm{a}$ & $100 \%$ & $0,00 \pm 0,00$ & $\mathrm{a}$ & $100 \%$ \\
\hline \multirow{3}{*}{ Perlakuan } & \multicolumn{21}{|c|}{ Rata-rata Kelimpahan A. gossypii (ekor per tanaman) pada (HSP) } \\
\hline & \multicolumn{3}{|l|}{8} & \multicolumn{3}{|l|}{9} & \multicolumn{3}{|c|}{10} & 11 & & & 12 & & & 13 & & & 14 & & \\
\hline & $(\mathrm{X} \pm \mathrm{SE})$ & & PP & $(\mathrm{X} \pm \mathrm{SE})$ & & PP & $(\mathrm{X} \pm \mathrm{SE})$ & & & $(\mathrm{X} \pm \mathrm{SE})$ & & PP & $(\mathrm{X} \pm \mathrm{SE})$ & & PP & $(\mathrm{X} \pm \mathrm{SE})$ & & PP & $(\mathrm{X} \pm \mathrm{SE})$ & & PP \\
\hline Kontrol & $237,50 \pm 73,80$ & $\bar{c}$ & & $291,50 \pm 74,55$ & $\mathrm{c}$ & & $361,25 \pm 71,83$ & $\mathrm{~b}$ & & $426,50 \pm 73,97$ & $\mathrm{~b}$ & & $485,00 \pm 70,81$ & $\mathrm{~b}$ & & $541,25 \pm 59,10$ & $\mathrm{~b}$ & & $603,75 \pm 55,00$ & $\mathrm{~b}$ & \\
\hline Bungkil biji mimba 25 gr & $17,25 \pm 4,44$ & $\mathrm{~b}$ & $93 \%$ & $10,50 \pm 2,72$ & $\mathrm{~b}$ & $96 \%$ & $4,25 \pm 1,89$ & $\mathrm{a}$ & $99 \%$ & $0,75 \pm 0,75$ & $\mathrm{a}$ & $100 \%$ & $0,00 \pm 0,00$ & $\mathrm{a}$ & $100 \%$ & $0,00 \pm 0,00$ & $\mathrm{a}$ & $100 \%$ & $0,00 \pm 0,00$ & $\mathrm{a}$ & $100 \%$ \\
\hline Bungkil biji mimba 50 gr & $6,50 \pm 2,60$ & $a b$ & $97 \%$ & $3,75 \pm 1,44$ & $a b$ & $99 \%$ & $1,25 \pm 0,95$ & $\mathrm{a}$ & $100 \%$ & $0,00 \pm 0,00$ & $\mathrm{a}$ & $100 \%$ & $0,00 \pm 0,00$ & $\mathrm{a}$ & $100 \%$ & $0,00 \pm 0,00$ & $\mathrm{a}$ & $100 \%$ & $0,00 \pm 0,00$ & $\mathrm{a}$ & $100 \%$ \\
\hline Bungkil biji mimba $75 \mathrm{gr}$ & $5,75 \pm 2,02$ & $\mathrm{ab}$ & $98 \%$ & $2,75 \pm 1,60$ & $a b$ & $99 \%$ & $1,75 \pm 1,03$ & $\mathrm{a}$ & $100 \%$ & $0,00 \pm 0,00$ & $\mathrm{a}$ & $100 \%$ & $0,00 \pm 0,00$ & $\mathrm{a}$ & $100 \%$ & $0,00 \pm 0,00$ & $\mathrm{a}$ & $100 \%$ & $0,00 \pm 0,00$ & $\mathrm{a}$ & $100 \%$ \\
\hline Bungkil biji mimba 100 gr & $0,50 \pm 0,50$ & $a b$ & $100 \%$ & $0,00 \pm 0,00$ & $\mathrm{a}$ & $100 \%$ & $0,00 \pm 0,00$ & $\mathrm{a}$ & $100 \%$ & $0,00 \pm 0,00$ & $\mathrm{a}$ & $100 \%$ & $0,00 \pm 0,00$ & $\mathrm{a}$ & $100 \%$ & $0,00 \pm 0,00$ & $\mathrm{a}$ & $100 \%$ & $0,00 \pm 0,00$ & $\mathrm{a}$ & $100 \%$ \\
\hline Bungkil biji mimba 125 gr & $2,50 \pm 1,44$ & $\mathrm{ab}$ & $99 \%$ & $1,00 \pm 0,58$ & $a b$ & $100 \%$ & $0,00 \pm 0,00$ & $\mathrm{a}$ & $100 \%$ & $0,00 \pm 0,00$ & $\mathrm{a}$ & $100 \%$ & $0,00 \pm 0,00$ & $\mathrm{a}$ & $100 \%$ & $0,00 \pm 0,00$ & $\mathrm{a}$ & $100 \%$ & $0,00 \pm 0,00$ & $\mathrm{a}$ & $100 \%$ \\
\hline Karbofuran & $0,00 \pm 0,00$ & $\mathrm{a}$ & $100 \%$ & $0,00 \pm 0,00$ & $\mathrm{a}$ & $100 \%$ & $0,00 \pm 0,00$ & $\mathrm{a}$ & $100 \%$ & $0,00 \pm 0,00$ & $\mathrm{a}$ & $100 \%$ & $0,00 \pm 0,00$ & $\mathrm{a}$ & $100 \%$ & $0,00 \pm 0,00$ & $\mathrm{a}$ & $100 \%$ & $0,00 \pm 0,00$ & $\mathrm{a}$ & $100 \%$ \\
\hline
\end{tabular}

Keterangan:

\section{HSP : Hari Setelah Perlakuan}

$X \quad$ : rata-rata kelimpahan populasi A. gossypii (ekor per tanaman)

SE : Standar Error

PP : Persentase penurunan populasi ((populasi kontrol-populasi perlakuan)/populasi kontrol) x100\%

Angka yang diikuti huruf yang sama pada setiap kolom tidak berbeda nyata menurut uji Duncan pada taraf nyata $5 \%$.

*: tidak berbeda nyata 
Tabel 2. Hasil analisis N-serapan setelah aplikasi bungkil biji mimba pada tanaman cabai.

\begin{tabular}{lc}
\hline \multicolumn{1}{c}{ Perlakuan } & N-serapan (mg/tanaman) \\
\cline { 2 - 2 } Kontrol & $\mathrm{X} \pm$ SD \\
Bungkil biji mimba 25 gr & $46,30 \pm 13,15$ \\
Bungkil biji mimba 50 gr & $109,80 \pm 36,69$ \\
Bungkil biji mimba 75 gr & $146,00 \pm 87,26$ \\
Bungkil biji mimba 100 gr & $59,10 \pm 1,06$ \\
Bungkil biji mimba 125 gr & $86,30 \pm 37,62$ \\
Karbofuran & $91,00 \pm 45,89$ \\
\hline
\end{tabular}

Keterangan:

$\mathrm{X}$ : rata-rata kadar $\mathrm{N}$-serapan pada tanaman cabai

SD : Standar Deviasi

Kandungan klorofil daun tanaman cabai merah yang diaplikasikan bungkil biji mimba

dosis bungkil biji mimba 50 gr per $3 \mathrm{~kg}$ tanah mampu meningkatkan kandungan klorofil paling tinggi sebesar 83,48 Chlorophyl Content Index (CCI) dibandingkan dengan tanpa perlakuan atau kontrol yang hanya memiliki kandungan klorofil sebanyak dilakukan pada pengukuran kandungan klorofil daun tanaman cabai menunjukkan bahwa pemberian dosis bungkil biji mimba berpengaruh nyata terhadap indeks kandungan klorofil daun. Perlakuan pemberian 43,46 CCI (Tabel 3).

Tabel 3. Pengaruh perlakuan pemberian bungkil biji mimba terhadap jumlah klorofil daun pada tanaman cabai.

\begin{tabular}{lc}
\hline \multicolumn{1}{c}{ Perlakuan } & Indeks kandungan klorofil (CCI) \\
\hline Kontrol & $43,46 \mathrm{a}$ \\
Bungkil biji mimba 25 gr & $64,42 \mathrm{~b}$ \\
Bungkil biji mimba 50 gr & $83,48 \mathrm{c}$ \\
Bungkil biji mimba 75 gr & $61,79 \mathrm{~b}$ \\
Bungkil biji mimba 100 gr & $61,78 \mathrm{~b}$ \\
Bungkil biji mimba 125 gr & $63,09 \mathrm{~b}$ \\
Karbofuran & $61,56 \mathrm{~b}$ \\
\hline
\end{tabular}

Keterangan :

Angka yang diikuti huruf yang sama pada setiap kolom tidak berbeda nyata menurut uji Duncan pada taraf nyata $5 \%$.

Jumlah $\mathrm{N}$-serapan pada tanaman berbanding lurus dengan jumlah kandungan klorofil pada tanaman. Tanaman dengan jumlah $\mathrm{N}$-serapan rendah memiliki kandungan klorofil yang dihasilkan juga rendah, yang selanjutnya berpengaruh pada minimnya kemampuan tanaman dalam melangsungkan aktivitas metabolismenya, terutama fotosintesis (Suminarti, 2010). Hal ini berhubungan dengan fungsi klorofil itu sendiri yang merupakan zat hijau daun yang mempunyai peran penting dalam proses fotosintesis tanaman. Saat kandungan klorofil dalam tanaman rendah maka akan berdampak pada rendahnya kemampuan tanaman dalam menyerap cahaya, yang selanjutnya akan berdampak pada rendahnya fotosintat yang dihasilkan (Tjondronegoro, 1981).

\section{Tinggi tanaman cabai merah yang diaplikasikan bungkil biji mimba}

Perlakuan pemberian bungkil biji mimba memberikan pengaruh yang berbeda nyata dengan kontrol pada pengamatan kedua yaitu hari ke-14 setelah perlakuan. Perlakuan pemberian dosis bungkil biji mimba sebanyak 50 gr per $3 \mathrm{~kg}$ tanah dapat meningkatkan tinggi tanaman paling signifikan dibanding dengan kontrol. Pada pengamatan pertama atau pada hari ke-7 setelah perlakuan, aplikasi bungkil biji mimba dapat meningkatkan tinggi tanaman namun tidak berbeda nyata saat dibandingkan dengan kontrol atau tanpa perlakuan (Tabel 4).

Aplikasi bungkil biji mimba dapat meningkatkan jumlah $\mathrm{N}$-serapan tanaman, sehingga berpengaruh terhadap peningkatan komponen pertumbuhan tanaman seperti tinggi tanaman (Arafa, 2004). Penelitian Bhalla \& Prasad (2008) melaporkan bahwa aplikasi bungkil biji mimba dapat meningkatkan secara signifikan pertumbuhan tanaman padi yang diukur melalui panjang daun, jumlah daun, jumlah anakan, dan tingkat warna hijau pada daun/jumlah klorofil pada daun. Lalnunpuia et al. (2018) juga menunjukkan bahwa pemberian bungkil biji mimba secara tunggal maupun ditambah pupuk NPK secara bersamaan dapat meningkatkan komponen pertumbuhan seperti tinggi tanaman, jumlah daun, jumlah cabang dibanding kontrol. 
Tabel 4. Pengaruh perlakuan pemberian bungkil biji mimba terhadap tinggi tanaman cabai.

\begin{tabular}{lccc}
\hline \multicolumn{1}{c}{ Perlakuan } & Tinggi $\mathrm{H} 0 *(\mathrm{~cm})$ & Tinggi $\mathrm{H} 7 *(\mathrm{~cm})$ & Tinggi $\mathrm{H14}(\mathrm{cm})$ \\
\hline Kontrol & $14,75 \mathrm{a}$ & $21,75 \mathrm{a}$ & $24,75 \mathrm{a}$ \\
Bungkil biji mimba 25 gr & $17,25 \mathrm{a}$ & $24,50 \mathrm{a}$ & $32,75 \mathrm{abc}$ \\
Bungkil biji mimba 50 gr & $20,75 \mathrm{a}$ & $25,50 \mathrm{a}$ & $35,00 \mathrm{bc}$ \\
Bungkil biji mimba 75 gr & $17,50 \mathrm{a}$ & $20,50 \mathrm{a}$ & $25,00 \mathrm{a}$ \\
Bungkil biji mimba 100 gr & $18,25 \mathrm{a}$ & $21,25 \mathrm{a}$ & $26,75 \mathrm{ab}$ \\
Bungkil biji mimba 125 gr & $20,50 \mathrm{a}$ & $23,50 \mathrm{a}$ & $30,00 \mathrm{abc}$ \\
Karbofuran & $23,50 \mathrm{a}$ & $29,25 \mathrm{a}$ & $38,25 \mathrm{c}$ \\
\hline
\end{tabular}

Keterangan:

HO : Tinggi tanaman awal sebelum perlakuan

H7 : Tinggi tanaman 7 hari setelah perlakuan

H14 : Tinggi tanaman 14 hari setelah perlakuan

Angka yang diikuti huruf yang sama pada setiap kolom tidak berbeda nyata menurut uji Duncan pada taraf nyata $5 \%$.

*: tidak berbeda nyata

Sahrawat \& Parmar (1975) dan Mishra (1975) juga melaporkan bahwa aplikasi bungkil biji mimba dapat memperlambat proses nitrifikasi melalui mekanismenya pada bakteri penambat N. Mekanisme yang terjadi antara lain dapat berupa peningkatan jumlah bakteri penambat $\mathrm{N}$ seperti Nitrosomonas yang dapat mengurangi proses kehilangan $\mathrm{N}$ secara bersamaan (Mishra, 1978). Mekanisme ini menyebabkan waktu penyerapan unsur hara dari bungkil biji mimba oleh tanaman cabai berlangsung lebih lama dan dapat mengurangi kehilangan unsur hara ke lingkungan karena sifat slow release dari bungkil biji mimba.

Kekerasan daun tanaman cabai merah yang diaplikasikan bungkil biji mimba

Pada penelitian ini, aplikasi bungkil biji mimba dapat memperngaruhi kekerasan daun tanaman cabai. Hal ini ditunjukkan dengan kekerasan daun tanaman cabai yang diaplikasikan dengan bungkil biji mimba lebih tinggi dibandingkan kontrol (Tabel 5). Kekerasan daun rata-rata pada tanaman cabai yang telah dianalisis pada kontrol adalah 2,20 $\mathrm{mm} /$ detik/gram, sedangkan pada perlakuan pemberian dosis bungkil biji mimba 25 gr, 50 gr, 75 gr, 100 gr, dan 125 gr berturut-turut memiliki kekerasan daun $1,80 \mathrm{~mm}$ detik ${ }^{-1}$ gram $^{-1}, 1,87 \mathrm{~mm}_{\text {detik }}{ }^{-1}$ gram $^{-1}, 1,79$ $\mathrm{mm} \operatorname{detik}^{-1}$ gram $^{-1}, 1,94 \mathrm{~mm} \operatorname{detik}^{-1}$ gram $^{-1}$, dan 1,79 $\mathrm{mm} \operatorname{detik}^{-1}$ gram $^{-1}$.

Berdasarkan prinsip kerja penetrometer, semakin besar nilai tingkat kekerasan maka semakin lunak sampel yang diuji, sedangkan jika semakin kecil nilai tingkat kekerasan maka semakin keras sampel yang diuji (Suwanto \& Hapsari, 2012). Data kekerasan daun tanaman cabai juga tidak dianalisis secara statistik karena hanya dua ulangan yang diukur dan hanya dihitung berdasarkan nilai rata-rata dari sampel yang dianalisis.

Tabel.5. Hasil analisis kekerasan daun setelah aplikasi bungkil biji mimba pada daun tanaman cabai.

\begin{tabular}{lc}
\hline \multirow{2}{*}{ Perlakuan } & Kekerasan Daun $\left(\mathrm{mm}\right.$ detik $\left.^{-1} 100 \mathrm{gr}^{-1}\right)$ \\
\cline { 2 - 2 } & $\mathrm{X} \pm \mathrm{SD}$ \\
\hline Kontrol & $2,20 \pm 0,04$ \\
Bungkil biji mimba 25 gr & $1,80 \pm 0,06$ \\
Bungkil biji mimba 50 gr & $1,87 \pm 0,24$ \\
Bungkil biji mimba 75 gr & $1,79 \pm 0,27$ \\
Bungkil biji mimba 100 gr & $1,94 \pm 0,03$ \\
Bungkil biji mimba 125 gr & $1,79 \pm 0,03$ \\
Karbofuran & $1,88 \pm 0,14$ \\
\hline Ken
\end{tabular}

\section{Keterangan:}

$\mathrm{X}$ : rata-rata kekerasan daun pada tanaman cabai

SD : Standar Deviasi

A. gossypii menyerang pada bagian daun dan pucuk tanaman cabai dengan cara menusukkan stiletnya dan menghisap cairan nutrisi pada daun dan pucuknya. Kekerasan pada jaringan pucuk tanaman cabai akan berpengaruh pada kemampuan A. gossypii untuk melakukan aktivitas makannya. Dari hasil percobaan tersebut, bungkil biji mimba terbukti dapat meningkatkan kekerasan daun tanaman cabai. 
Kekerasan daun tanaman juga memiliki korelasi dengan tingkat resistensi tanaman terhadap serangan serangga. Hasil penelitian Singh \& Jotwani (1980) menunjukkan bahwa tingkat kekerasan daun dan batang tanaman sorgum terkait resistensinya terhadap Atherigona soccata.

Peningkatan serapan unsur nitrogen pada tanaman dapat meningkatkan ketebalan dinding sel pada tanaman dimana saat ketebalan dinding sel tanaman meningkat juga dapat meningkatkan ketahanan tanaman terhadap serangan hama (War et al., 2012). Mekanisme peningkatan kekerasan daun ini dapat mengurangi palatibilitas dan digestibilitas dari jaringan daun tanaman, yang nantinya dapat mengurangi kerusakan daun (Hanley et al., 2007)

Hal ini didukung oleh Peter et al. (2011) bahwa tingkat kekerasan dan kelimpahan jaringan tanaman memiliki pengaruh yang signifikan terhadap performa individu, kelimpahan populasi serta struktur alat makan pada serangga. Chandramani (2009) juga menyebutkan bahwa bungkil biji mimba yang diaplikasikan sebagai pupuk organik pada tanaman padi dapat meningkatkan kandungan kalium dan silika yang dapat meningkatkan kekerasan pada batang padi dan memicu resistensi pada tanaman tersebut.

Pernyataan tersebut juga didukung oleh penelitian Pollard (1973) yang melaporkan bahwa kekerasan jaringan berperan dalam mempengaruhi kemampuan penetrasi stilet Aphis fabae dan Myzus persicae saat menembus lapisan korteks atau mesofil pada daun. Iheagwan (2009) juga melaporkan bahwa tingkat kekerasan daun tanaman mempengaruhi fekunditas serta kemampuan penetrabilitas dari kutu putih kubis_Aleyroides brassicae.

\section{Intensitas kerusakan daun tanaman cabai merah akibat kutu daun A.gossypii yang diaplikasikan bungkil biji mimba}

Perlakuan aplikasi dosis bungkil biji mimba berpengaruh nyata terhadap persentase kerusakan daun. Semakin tinggi populasi kutu daun maka semakin tinggi persentase kerusakan daun. Semua tanaman yang diberi perlakuan pemberian bungkil biji mimba memiliki tingkat kerusakan yang lebih rendah dibanding dengan kontrol (Tabel 6).

Tabel 6. Persentase gejala kerusakan daun cabai oleh A. gossypii

\begin{tabular}{lllll}
\hline \multirow{2}{*}{ Perlakuan } & \multicolumn{4}{l}{ Rata-rata Kerusakan Daun Cabai oleh Aphis gossypii (\%) } \\
\cline { 2 - 5 } & 7 hari setelah aplikasi & c & 28,83 & $\mathrm{~d}$ \\
\hline Kontrol & 29,00 & $\mathrm{a}$ & 10,06 & $\mathrm{abc}$ \\
Bungkil biji mimba 25 gr & 8,22 & $\mathrm{ab}$ & 9,01 & $\mathrm{ab}$ \\
Bungkil biji mimba 50 gr & 9,69 & $\mathrm{ab}$ & 15,50 & $\mathrm{c}$ \\
Bungkil biji mimba 75 gr & 14,58 & $\mathrm{~b}$ & 14,55 & $\mathrm{bc}$ \\
Bungkil biji mimba 100 gr & 16,39 & $\mathrm{ab}$ & 12,16 & $\mathrm{abc}$ \\
Bungkil biji mimba 125 gr & 11,03 & $\mathrm{a}$ & 6,4 & $\mathrm{a}$ \\
\hline
\end{tabular}

Keterangan : Angka yang diikuti huruf yang sama pada setiap kolom tidak berbeda nyata menurut uji Duncan pada taraf nyata $5 \%$.

Pada pengamatan pertama pada hari ke-7, tingkat kerusakan antar perlakuan berbeda nyata. Tanaman kontrol mengalami kerusakan daun paling tinggi yaitu dengan rata-rata $29 \%$. Kerusakan daun paling kecil ada pada perlakuan aplikasi insektisida bahan aktif karbofuran. Hal ini disebabkan karena pada hari ke-6 setelah aplikasi populasi kutu daun $A$. gossypii sudah mengalami penurunan populasi sebesar $100 \%$. Sementara pada pengamatan hari ke14 , tanaman yang tanpa diberi perlakuan atau kontrol tetap mengalami kerusakan daun paling tinggi yaitu dengan rata-rata $28,83 \%$ karena pada perlakuan kontrol populasi kutu daun A. gossypii terus meningkat. Adapun kerusakan daun paling kecil tetap pada perlakuan aplikasi insektisida bahan aktif karbofuran.

Kerusakan pada tanaman yang diberi aplikasi bungkil biji mimba lebih kecil dibanding kontrol diduga disebabkan karena adanya mekanisme induksi ketahanan pada tanaman karena terdapat peningkatan signifikan kadar N-serapan, jumlah klorofil dan kekerasan daun (Handley et al., 2005). Hal ini didukung oleh pernyataan Agrawal et al. (2009) yang melaporkan bahwa peningkatan karakter struktural daun seperti kekerasan daun dapat meningkatkan ketahanan tanaman dan meminimalisir efek dari serangan hama. Kerusakan daun akibat kutu daun berupa gejala daun keriting, daun mengalami distorsi, gejala klorosis, dan bercak daun (Cheewawiryakul et al., 2006).

\section{Gejala fitotoksik pada tanaman cabai merah yang diaplikasikan bungkil biji mimba}

Berdasarkan percobaan yang dilakukan, tidak terlihat terjadinya fitotoksisitas pada perlakuan pemberian dosis bungkil biji mimba maupun insektisida bahan aktif karbofuran. Gejala fitotoksik pada tanaman dapat diamati dengan melihat gejala yang muncul pada daun seperti gejala terbakar atau gosong (Kardinan \& Suriarti, 2012). Gejala fitotoksik juga dapat diidentifikasi apabila adanya klorosis, 
sebagian atau seluruh tanaman lebih kecil, pertumbuhan yang abnormal. Gejala fitotoksik muncul pada waktu relatif singkat setelah aplikasi, serta tidak menyebar ke tanaman lainnya (Moorwan, 2011). Pada penelitian ini gejala-gejala fitotoksik tersebut di atas tidak ditemukan pada tanaman percobaan. Gejala klorosis pada tanaman cabai disebabkan oleh serangan A. gossypii dan bukan karena aplikasi bungkil biji mimba.

\section{KESIMPULAN DAN SARAN}

\section{Kesimpulan}

Berdasarkan hasil penelitian, dapat diambil simpulan sebagai berikut:

1. Aplikasi bungkil biji mimba dapat mempengaruhi karakter pertumbuhan cabai seperti peningkatan tinggi tanaman dan jumlah klorofil daun. Selain itu bungkil biji mimba juga dapat meningkatkan kekerasan jaringan daun tanaman serta jumlah $\mathrm{N}$ serapan. Sebagai implikasinya hal tersebut dapat meningkatkan ketahanan tanaman cabai terhadap A. gossypii.

2. Dosis aplikasi bungkil biji mimba $50 \mathrm{~g}$ per 3 $\mathrm{kg}$ tanah paling efektif dalam menekan populasi kutu daun $A$. gossypii serta dapat mempengaruhi beberapa karakter pertumbuhan tanaman cabai misalnya tinggi tanaman, jumlah klorofil daun, kekerasan jaringan daun tanaman serta jumlah $\mathrm{N}$ serapan.

\section{UCAPAN TERIMA KASIH}

Penelitian ini merupakan bagian dari penelitian yang berjudul Formulasi Insektisida Botani Ekstrak Biji Azadirachta Indica: Peningkatan Bioaktivitas Berbasis Kombinasi Campuran Bahan Nabati dengan peneliti utama Danar Dono melalui skema Hibah Internal Universitas Padjadjaran (HIU) tahun 2019-2021. Kepada Rektor Universitas Padjadjaran disampaikan terima kasih.

\section{DAFTAR PUSTAKA}

Agrawal AA, Janssen A, Bruin J, Posthumus MA, \& Sabelis MW. 2002. An ecological cost of plant defence: attractiveness of bitter cucumber plants to natural enemies of herbivores. Ecol Lett 5:377-85

Agrorganix. 2018. Neem cake. Tersedia di http://www.agrorganix.com/product/neemcake, diakses pada 18/05/2018.

Arafa. 2004. Effect of different NPK treatments on growth, yield, quality and chemical components of two potato cultivars. Annals of Agricultural Science. 42(2):753-766.

Arizona. 2001. Rearing aphid. University of Arizona. Tersedia di http://insected.arizona.edu/gg/ resource/rearing.html diakses pada 26/05/ 2018.

Basharat AP, Khalid AM, \& Fazili M. 2003. Physochemical parameters and growth yield of tomato (Lycopersicum esculentum) : Role of farm yard manure and neemcake. AmericanEurasian J. Agric. Enviorn. Sci., 2(3): 303307.

Bhalla RS \& Prasad KVD. 2008. Neem cake-urea mixed applications increase growth in paddy. Curr. Sci. 94: 1066-1070.

Blackman RL \& Eastrop VF. 2000. Aphids on The Word's Crops. An Identification \& Information Guide. Second Edition. Cromwell Road, London. The Natural History Museaum. pp 466.

Chandramani P, Rajendran R, Sivasubramanian P, \& Muthiah C. 2009. Impact of biophysical factors as influenced by organic sources of nutrients on major pests of rice. Journal of Biopesticides 2:1-5.

Cheewawiriyakul S, Conn K, Gabor B, Kao J, \& Salati R. 2006. Pepper and eggplant disease guide. Seminis. 72 hal. Tersedia di https://www.seminis.com/global/us/growerre sources/ documents/SEM12095_PepperDiseases_8p5 x11_072313.pdf, diakses pada 23/01/2018.

Da Costa JG, Pires EV, Riffel A, Birkett MA, Bleicher E, \& Sant'Ana AEG. 2011. Differential preference of Capsicum spp. cultivars by Aphis gossypii in conferred by variation in volatile semiochemistry. Euphytica, 177(3): 299-307.

Debashri \& Tamal. 2012. Kandungan biji dan daun mimba. Cancer Chemoprevention Research Center. Fakultas Farmasi Universitas Gadjahmada.

http://ccrc.farmasi.ugm.ac.id/?page_id=419, diakses pada 10/10/2017.

Ebert TA, Fargo WS, Cartwright B, \& Hall FR. 1998. Randomization tests: using morphological differences in Aphis gossypii (Homoptera: Aphididae). Ann. Entomol. Soc. Am. 91:761770.

Giraddi RS, \& Varghese TS. 2007. Effect of different levels of neem cake, vermicompost and green manure on sucking pests of chilli. 13(2): $108-114$.

Handley R, Ekbom B, \& Agren J. 2005. Variation in trichome density and resistance against a specialist insect herbivore in natural populations of Arabidopsis thaliana. Ecol Entomol 30:284-292

Hanley ME, Lamont BB, Fairbanks MM, \& Rafferty CM. 2007. Plant structural traits and their role in antiherbivore defense. Perspec. Plant Ecol Evol Syst 8: 157-78 
Kardinan A. \& Dhalimi A. 2003. Mimba (Azadirachta indica A. JUSS): Tanaman multi manfaat. Perkembangan Teknologi TRO. 15(1): 1-10.

Kardinan A \& Suriarti S. 2012. Efektivitas pestisida nabati terhadap serangan hama pada teh (Camelia sinensis L.). Bul. Litro. 23(2): 148152.

Kraiss H, \& Cullen EM. 2008. Insect growth regulator effects of azadirachtin and neem oil on survivorship, development and fecundity of Aphis glycines (Homoptera: Aphididae) and its predator, Harmonia axyridis (Coleoptera: Coccinellidae). Pest Management Science 64: 660-668

Lalnunpuia AA, David SH, Mahzar T, Thomas, \& Rao S. 2018. Effect of different level of fertilizers and neem cake on attributes and yield of potato (Solanum tuberosum L.). Int. J. Appl. Res. 3(4): 196-199.

Leite GLD, Picanço M, Zanuncio JC, \& Gusmão MR. 2007. Factors affecting colonization and abundance of Aphis gossypii GLOVER (Hemiptera: Aphididae) on okra plantations. Ciência e Agrotecnologia 31(2): 337-343.

Mangel K, \& Kirby EA. 1987. Principles of Plant Nutrition. 4th Edition. International Potash Institute.Worblaufen-Bern, Switzerland.

Miles PW. 1987. Feeding process of aphidoidea in relation to effects on their food plants in Minks AK and Harrewijn P (Eds.), Aphids: Their Biology, Natural Enemies and Control. Vol 2A. Elsevier: Amsterdam. pp. 321-340.

Mishra KC, \& Choonkar PK. 1978. Possible utilization of neem cake for inhibiting nitrification in soil. J. Indian Soc. Soil. Sci. 26: 90-92.

Mishra MM, Neelakantan S, \& Khandelwal SR. 1975. Margosa (Neem) seed cake as an inhibitor of nitrification. Soil. Prio-I-Biochem. 7: 183184.

Moorwan GW. 2011. Phytotoxicity. Penn State Extention. Available at https://extension.psu. edu/phytotoxicity. Pennsylvania State University.

Nathan SS, Choi MY, Paik CH, Seo HY, Kim JD, \& Kang SM. 2007. The toxic effects of neem extract and azadirachtin on the brown planthopper, Nilaparvata lugens (Stål) (BPH) (Homoptera: Delphacidae). Chemosphere 67(1): 80-88.

Neempedia. 2018. Quantity of neem cake necessary according to crop. Tersedia di https:// neempedia.com/neem-organic-complexity/ diakses pada $5 / 1 / 2018$.

Nevo E, \& Coll M. 2001. Effect of nitrogen fertilization on Aphis gossypii (Homoptera: Aphididae): Variation in size, color, and reproduction. J. Econ. Entomol. 94(1): 2732.

Opoku A, Chaves B, \& De Neve S. 2014. Biological agriculture and horticulture : an international journal for neem seed oil: a potent nitrification inhibitor to control nitrate leaching after incorporation of crop residues. : 37-41.

Pavela R, Barnet M, \& Kocourek F. 2004. Effect of azadirachtin applied systemically through roots of plants on the mortality, Development and Fecundity of the Cabbage Aphid (Brevicoryne brassicae). Phytoparasitica 32(3):286-294.

Peter WP, Denno, Robert F, Eubanks, Micky D, Finke, Deborah L, \& Kaplan I. 2011. Insect ecology: behavior, populations and communities. Cambridge University Press, New York. pp 117.

Pollard DG. 1973. Plant penetration by feeding aphids (Hemiptera, Aphidoidea): A review. Bull. Entomol. Res. 62(4): 631-714.

Rao K. 2012. Neem (Azadirachta indica). http://www. oilseedcrops.org/wp-content/uploads/2012/11 /Indian-Neem-Growth.pdf, diakses pada 08/10/2017.

Rao P, \& Udayasekhara. 1987. Chemical composition and biological evaluation of debitterized and defatted neem (Azadirachta indica) seed kernel cake. Journal of the American Oil Chemists Society. 64(9):1348-1351.

Riyanto D, Zen, \& Arifin Z. 2016. Studi biologi kutu daun (Aphis gossypii GLOVER). J. Pembelajaran Biol. 3(2): 146-152.

Rosenheim JA, Wilhoit LR, \& Colfer RG. 1994. Seasonal biology and polymorphism of the cotton aphid, Aphis gossypii, in California, pp. 125-131. In Proceedings of the Beltwide Cotton Conference, 8 January 1994, San Diego, CA. National Cotton Council of America, Memphis, TN.

Roychoudhury R. 2016. Neem Products. Ecofriendly Pest Manag. Food Secur.: 563-611.

Saenong MS. 2016. Tumbuhan Indonesia potensial sebagai insektisida nabati untuk mengendalikan hama kumbang bubuk jagung (Sitophilus

J. Litbang Pertan. 35: 131-142.

spp.).

Sahrawat KL, \& Parmar BS. 1975. Alcohol extract of neem (Azadirachta indica L.) seed as nitrification inhibitor. Journal of the Indian Society of Soil Science 23(1):131-134.

Salaki CL, \& Pelealu J. 2012. Pemanfaatan Baringtonia asiatica dan Annona muricata terhadap serangga vektor penyakit pada tanaman cabai. Jurnal Eugenia 18(1):22-34

Samsudin. 2011. Biosintesa dan cara kerja azadirachtin sebagai bahan aktif insektisida nabati. Balai Penelitian Tanaman Rempah dan Aneka Tanaman Industri. Hasil Prosiding Seminar Nasional Pestisida Nabati IV, Jakarta. Halaman 61-70. 
Saptana N, Khoriyah, \& Ar-Rozi AM. 2012. Kinerja produksi dan harga komoditas cabai merah. Tersedia di http://pse.litbang.pertanian.go.id/ ind/pdffiles/anjak_2012_10.pdf, diakses pada 12/01/2018.

Saxena RC, Justo HD, \& Epino PB. 1984. Evaluation and utilization of neem cake against Homoptera: Delphacidae. Journal of Economic Entomology 77:2.

Saxena RC. 2015. Mimba untuk Pengendalian Hama dan Konservasi Lingkungan yang Berkelanjutan. Diterjemahkan oleh: Tyas Budi Utami. Thailand. ECHO Asia Foundation. 24:1-27

Sinha R, Singh B, Rai PK, Kumar A, Jamwal S, \& Sinha BK. 2018. Soil fertility management and its impact on mustard aphid, Lipaphis erysimi (Kaltenbach) (Hemiptera: Aphididae). Cogent Food Agric. 4(1): 1-12.

Suminarti NE. 2010. Pengaruh pemupukan N dan K pada pertumbuhan dan hasil tanaman talas yang ditanam di lahan kering. Akta Agrosia 13(1): 1-7.

Sundaram KMS, Campbell R, Sloane L, \& Studens J. 1995. Uptake, translocation, persistence and fate of azadirachtin in aspen plants (Populus tremuloides Michx.) and its effect on pestiferous two-spotted spider mite (Tetranychus urticae Koch). Crop Protection 14(5):415-421.

Sundaram KMS. 1996. Root uptake, translocation, accumulation and dissipation of the botanical insecticide, azadirachtin, in young spruce trees. Journal of Environmental Science and Health. 31(6), 1289-1306.
Suwanto EP, \& Hapsari YD. 2012. Studi dan perancangan penetrometer digital sebagai alat uji konsistensi bahan berbasis mikrokontroler. Journal of Chemical Information and Modeling, 53(9).

Tjondronegoro P, Prawiranata W, \& Harran S. 1981. Dasar-dasar Fisiologi Tumbuhan I. Dept. Botani. FP. IPB, Bogor.

Walker PT. 1991. Measurement of insect populations and injury in crop loss assessment and pest management. APS Press the American Phytopathological Society. St. Paul Minnesota. pp. 19-29.

War AR, Paulraj MG, Buhroo AA, Ignacimuthu S, Sharma HC, Hussain B, \& Ahmad T. 2012. Mechanisms of plant defense against insect herbivores. Plant Signaling \& Behavior 7(10): 1306-1320.

Weathersbee AA, \& McKenzie CL. 2005. Effect of a neem biopesticide on repellency, mortality, oviposition, and development of Diaphorina citri (Homoptera: Psyllidae). BioOne 88(4): 401-407.

Wowiling J. 2010. Pestisida nabati Mimba (Azadirachta indica A.Juss) dalam pengendalian organisme pengganggu tumbuhan (OPT). Balai Pengkajian Teknologi Pertanian (BPTP). Sulawesi.

Yusriah. 2017. Formulasi minyak bungkil mimba dengan surfaktan DEA untuk pengendalian Spodoptera litura pada tanaman kedelai. Skripsi. Tersedia online di https://repository. ipb.ac.id/handle/123456789/91526 (diakses 24 Maret 2018). 